\title{
LUIS BRIONES Y LOS GEOGLIFOS DEL DESIERTO DE ATACAMA EN MOVIMIENTO
}

\author{
Daniela Valenzuela ${ }^{1}$
}

Luis Briones fue un pionero en el estudio de los geoglifos en el norte de Chile. Aunque los geoglifos habían sido descritos por viajeros y estudiosos del siglo XIX y XX (p.ej., Bollaert 1860; Plagemann 1906), hasta la década de 1970 no se habían considerado de manera sistemática, con la excepción de Schaedel (1957). Los primeros estudios sistemáticos fueron llevados a cabo por él, a partir de la década de 1970.

Luis Briones no solo abrió una línea de investigación posicionando a los geoglifos como un artefacto cultural a ser estudiado desde una perspectiva arqueológica, sino que instauró una metodología de registro (Briones 1984), restauración y conservación sin precedentes, que sigue siendo utilizada hasta el día de hoy (Briones y Casanova 2011). El legado de Lucho es muy amplio, tal como se refleja en algunas de sus artículos de síntesis (Briones 2006); aquí solo me referiré a algunas de sus contribuciones que pienso están estrechamente conectadas con sus cualidades personales.

$\mathrm{Y}$ es que pienso que la perspectiva de Lucho en relación con los geoglifos está directamente conectada con su experiencia vivida, de su capacidad extraordinaria para conectarse con el territorio, con el paisaje. Sus ideas emanaron sobre todo desde su percepción, no solo visual sino también corporal, de su experiencia fenoménica de la observación visual de las imágenes y del recorrido de su propio cuerpo en el espacio. Él recorrió -en vehículo y a pie- gran parte del desierto, los senderos y las pampas asociadas a los geoglifos. Lucho nunca pudo concebir a los geoglifos y el espacio circundante como dos fenómenos desconectados; esta incapacidad para desligarlos fue clave en sus interpretaciones, y de alguna manera tenía que ver con el ser pampino y nortino, el haber vivido en el desierto y haber jugado de niño a explorar ese desierto:

...les confieso que con todos estos años de contacto y diálogos ocultos con los geoglifos del desierto, gozo una extraña sensación de estar asimilándome a ellos, en su relación con el entorno donde se les encuentra, y por qué no imaginar que ¡algún día llegaré a estar plasmado en uno de ellos! (...) la visión que tengo de los geoglifos y de los contextos culturales y naturales que les rodean, desde mi perspectiva de nortino y pampino, de cuando siendo niño jugábamos, junto a otros amigos, a explorar el desierto tarapaqueño (Briones 2009:15).

Esta experiencia vivida le proporcionó sutilezas únicas. Por ejemplo, describió en más de alguna oportunidad cómo la percepción visual de los geoglifos, ya sea de una sola figura o de un conjunto, muchas veces estaba condicionada por el desplazamiento de las personas y el movimiento de las personas a través de una ruta; solo a partir de ese desplazamiento y movimiento se podría percibir (visual y corporalmente) una escena, como una suerte de secuencia espaciotemporal, una serie de capturas en movimiento que en conjunto y secuencialmente permitían comprender una escena visual:
(...) el mensaje visual no siempre requiere una actitud estática del observador, es decir. su ubicación desde uno o dos puntos del entorno geográfico; hay numerosos casos que requieren el desplazamiento del espectador para apreciar el panel o la secuencia que se ha querido representar como una unidad (...) Es decir, a través del desplazamiento de las caravanas los conjuntos de diseños son observados en su real amplitud (Briones 1984:43).

Esto él lo pudo constatar a partir de su propia experiencia, no a partir de dibujos, no a partir del puro

1 Departamento de Antropología, Universidad de Tarapacá, Arica, Chile, dani.valenzu@gmail.com 
registro. Cómo olvidar su magistral ponencia "Sendero luminoso, una realidad en el desierto" presentada en el XV Congreso Nacional de Arqueología Chilena (Arica, 2000), remarcando la posibilidad de observación de los senderos troperos durante la noche, tomando prestado el nombre del movimiento revolucionario peruano cuyos inicios, según sus propias palabras, tuvo la oportunidad de conocer de cerca en la zona de Ayacucho, Perú (Briones 2001).

En esta idea de que los geoglifos estaban tan vinculados con el paisaje, que eran parte de lo mismo, que era una distinción puramente analítica, algo que hoy no se discute, lo tenía claro desde mucho antes. En ese sentido, él consideraba que el desierto fue el escenario ideal, más apropiado y preciso para desarrollar los geoglifos.

Lucho Briones, como artista y profesor de artes plásticas, tenía también esa sensibilidad visual muy particular; él podía ver cosas que nadie más podía ver, identificar ciertas figuras, podía hacer un seguimiento mental de determinados motivos en diferentes sitios y ver ciertas transformaciones (Chacama y Briones 2003). Incluso en algún momento dijo que puede a veces reconocer al mismo autor, porque veía cómo una figura se iba replicando, con ciertas variaciones en términos espaciales y también temporales.
Todo el cúmulo de conocimientos aportados por los estudios de Luis Briones en el ámbito metodológico (Briones 1984; Clarkson y Briones 2001; Clarkson et al. 1999), en el inventario y registro (Briones y Castellón 2005), en la conservación y puesta en valor de los sitios de geoglifos (Briones y Álvarez 1984; Briones y Casanova 2011), en estudios contextuales (Briones y Chacama 1987), interpretativos (Briones et al. 1999; Briones et al. 2005) y trabajos de síntesis (Briones 2006, 2008), es incalculable, aunque para él mientras más conocía, menos sabía:
Tal como sucede cuando se cree saber y conocer más sobre un tema determinado, en este caso de geoglifos, concluyo que solo he logrado acrecentar mi ignorancia al respecto. Puedo decir con cierta certeza cuántos geoglifos son y cuántos ya no son, cómo los hicieron, cómo localizarlos, cómo se conservan, quién o quiénes los destruyen, etc., pero responder qué significan, quién o quiénes los hicieron, para qué los hicieron, etc., es materia muy compleja y difícil de aclarar y definir (Briones 2009:15).

\section{Referencias Citadas}

Bollaert, W. 1860. Antiquarian, Ethnological and other researches in New Granada, Ecuador, Perú and Chile, with observations of the Pre-Incaria, Incarial, and other monuments of Peruvian Nation. Trüber \& Co., London.

Briones, L. 1984. Fundamentos para una metodología aplicada al relevamiento de los geoglifos del norte de Chile. Chungara Revista de Antropología Chilena 12:41-56.

Briones, L. 2001. Sendero Luminoso, una realidad en el desierto. En: Contextualización de los geoglífos en el desierto tarapaqueño, analisis de distribución espacial, contextos culturales y recursos asociados. Informe final de investigación Proyecto N 3746-97.

Briones, L. 2006. The geoglyphs of the north Chilean desert: An archaeological and artistic perspective. Antiquity 80:9-24.

Briones, L. 2008. Geoglifos del Norte de Chile. Región de Arica y Parinacota. Salesianos Impresores /Consejo de Monumentos Nacionales, Arica.

Briones, L. 2009. Geoglifos y paisaje en el desierto del norte de Chile. En Crónicas sobre la Piedra. Arte Rupestre de las Américas, editado por M. Sepúlveda, L. Briones y J. Chacama, pp. 15-24. Ediciones Universidad de Tarapacá, Santiago.

Briones, L. y L. Álvarez 1984. Presentación y valoración de los geoglifos del norte de Chile. Estudios Atacameños 7:296-305.

Briones, L. y M.P. Casanova 2011. Conservación y Restauración de Geoglifos en el Norte de Chile. Centro de Investigaciones del Hombre en el Desierto / Consejo Nacional de la Cultura y las Artes, Arica.

Briones, L. y C. Castellón 2005. Catastro de geoglifos. Provincia de Tocopilla, Región de Antofagasta, Chile. pp. Consejo Nacional de la Cultura y las Artes; FONDART, Tocopilla.
Briones, L. y J. Chacama 1987. Arte rupestre de Ariquilda: análisis descriptivo de un sitio con geoglifos y su vinculación con la prehistoria regional. Chungara Revista de Antropología Chilena18:15-66.

Briones, L., P.B. Clarkson, A. Díaz y C. Mondaca 1999. Huasquiña, las chacras y los geoglifos del desierto: una aproximación al arte rupestre andino. Diálogo Andino 18:39-61.

Briones, L., L. Núñez y V.G. Standen 2005. Geoglifos y tráfico prehispánico de caravanas de llamas en el Desierto de Atacama (norte de Chile). Chungara Revista de Antropología Chilena 37 (2):195-223.

Chacama, J. y L. Briones 2003. El juego de la falcónida. Boletín de la Sociedad Chilena de Arqueología 35/36:81-85.

Clarkson, P.B. y L. Briones 2001. Geoglifos, senderos y etnoarqueología de caravanas en el desierto chileno. Boletín del Museo Chileno de Arte Precolombino 8:33-45.

Clarkson, P.B., L. Briones, G. Johnson y E. Johnson 1999. La percepción de los geoglifos por visión aérea. Boletín SIARB, Sociedad de Investigación del Arte Rupestre de Bolivia 13:46-52.

Plagemann, A. 1906. Über die chilenischen 'Pintados'. Beitrag zur Katalogisierung und vergleichenden Untersuchun der südamerikanischen Piktographien. W. Kohlhammer, Stuttgart.

Schaedel, R.P. 1957. Informe general sobre la expedición a la zona comprendida entre Arica y La Serena. En Arqueología Chilena. Contribuciones al Estudio de la Región Comprendida entre Arica y La Serena, editado por R.P. Schaedel, pp. 5-42. Centro de Estudios Antropológicos, Universidad de Chile, Santiago. 
